UDC 37.016:004+37.091.12.046-021.68:004](07)

\title{
Olena O. Hrytsenchuk
}

$\mathrm{PhD}$ of Pedagogical Sciences,

Senior Researcher of the Comparative Studies Department for Information and Education Innovations

Institute of Information Technologies and Learning Tools of NAES of Ukraine, Kyiv, Ukraine

ORCID ID 0000-0003-3173-7649

helenakyiv2017@ukr.net

\section{Oksana V. Ovcharuk}

Doctor of Pedagogical Sciences,

Senior Researcher, Head of the Comparative Studies Department for Information and Education Innovations Institute of Information Technologies and Learning Tools of NAES of Ukraine, Kyiv, Ukraine

ORCID ID 0000-0001-7634-7922

oks.ovch@hotmail.com

\section{Sergii I. Trubachev}

$\mathrm{PhD}$ of Technical Sciences, Associate Professor,

Lecturer of the Department of Dynamics and Strength of Machines and Resistance of Materials MMI

National Technical University of Ukraine "Igor Sikorsky Kyiv Polytechnic Institute", Kyiv, Ukraine

ORCID ID 0000-0002-7349-9426

strubachev@i.ua

\section{EFFICIENCY OF USING THE INFORMATION AND DIGITAL LEARNING ENVIRONMENT AS A TOOL OF DEVELOPING TEACHERS' CIVIC COMPETENCE}

\begin{abstract}
The article deals whih the results of the experimental verification of the methodology of use the information and digital learning environment as a tool for the development of teachers' civic competence. The experimental verification was carried out during a comprehensive study in 2018-2019. The authors of this study diagnosed the level of developing teachers' civic competence by questionnaires (incoming and outgoing) in the control (122 people) and experimental (129 people) groups. The description of criteria, levels and descriptors of assessment of civic competence of a teacher in an information and digital learning environment is given. Particular attention is paid to the attitude of teachers, school principals, methodologists and in-service teacher training specialists to the use of information and communication technologies (ICT) to create and develop an information and digital learning environment in educational institutions, and the use of digital tools in in-service teacher training institutions for civic education in schools. The purpose of the article is to prove the effectiveness of the methodology of using the information and digital learning environment as a tool for increasing teachers' level of civic competence and to highlight the process of the implementation of civic education in Ukrainian schools. In this study we have developed the main components of the methodology of using the information and digital learning environment as a means of developing teachers' civic competence, which constitutes the novelty of the study. The information and digital learning environment is an effective tool for raising the level of teachers' civic competence and a tool for implementing civic education in secondary school, which is the practical significance of the study.
\end{abstract}

Keywords: civic education; civic competence; information and communication competence; methodology; information and digital learning environment; experimental verification.

\section{INTRODUCTION}

The modern agenda of education in the high-tech digital age is the development of an open, technologically rich, pedagogically filled learning environment focused on educational priorities. Teachers, students and schools are active participants of teaching, education and professional activities in this environment, which has appropriate conditions for learning, 
development and exchange of experience. Teachers play a key role in the implementation of civic education in schools, so the level of their training is very important. The use of a rich arsenal of digital tools in the information and digital learning environment of a school is particularly important. This study was conducted in the framework of the research at the Institute of Information Technologies and Learning Tools of the National Academy of Educational Sciences of Ukraine ("The development of teachers' information and communication competence under conditions of cloud-based learning environment", 20172019 (№ 0117U000198); "Development of the informational and digital learning environment of Ukrainian school”, 2020-2022 (№ 0120U100193).

The use of ICT by teachers, their ability to operate digital tools for professional activities and their own professional growth are directly related to the manifestation of their civic position in the information and digital learning environment in particular. It is a combined socio-pedagogical phenomenon, which includes two related categorical domains, namely: the first category is related to ICT and the information and digital learning environment, and the second category is related to the sphere of citizenship education. The first category includes, in particular, the information and communication competence of the teacher and the information and digital learning environment. Teachers have to use digital tools and technologies, be able to interact, carry out their professional activities. The second categorical domain of the survey is related to the issues of awareness and realization of a teacher as a citizen, member of society, responsible professional who expresses civic position, promotes civic competence of students, reveals active social position. This domain, in particular, includes the teacher's civic competence as a component of professional competence. This study is based on the intersection of these categorical domains.

Analysis of recent studies and publications. Issues of the ICT-based learning environment are reflected in the works of modern Ukrainian researchers V. Bykov [1], S. Lytvinova [2], S. Semerikov [3], M. Shyshkina [4], V. Lugovy [1], V. Oliynyk [1], O. Burov [1], M. Striuk [3], O. Spirin [1] and others. Among the foreign scholars who study the issues of a comprehensive and systematic approach to the organization of the educational process by means of ICT are M. Schols, J. Bottema [5] and others, the problem of development of ICT competence of a teacher is revealed in the works of P. Fisser, M. Phillips [6]. The authors focus on the use of digital educational environment, in which teachers develop key competencies, including civic and information and communication competencies. The approaches to the use of the cloud based and e-based learning tools are revealed in the works of M.Shyshkina [3], N.Soroko [7], I.Malicka [8] and others. The principles of the competence approach in education and the problem of the development of civic competence are covered in the works of the following Ukrainian and foreign scholars: I.Ivaniuk [9], O. Ovcharuk [10], M. Leshchenko [11], K. Duerr [12], T.Olgers [13] and others.

\section{RESEARCH METHODS}

The following methods were used to attain the goal of this study: analysis, synthesis, generalization and systematization of scientific sources - to determine the theoretical, methodological and applied aspects of the development of teachers' civic and information and communication competencies by information and digital learning environment and to interprete the results obtained during experimental research; empirical methods, in particular, questionnaires, surveys, interviews - to find out teachers' attitude to the use of ICT in the process of civic education; methods of calculation and data processing. The questionnaire was based on international framework documents, the main of which are the Digital Competence Framework for Educators (2017) [14] and the Council of Europe Reference Framework of Competences for Democratic Culture (2018) [15]. 


\section{RESEARCH RESULTS}

The information and digital learning environment should be considered not only in the context of teachers'educational and practical activities as agents of the educational process. Educators interact with all participants of the educational process in the educational environment. This environment includes both participants and learning tools along with content, subject areas and relationships between all participants. At the curriculum level, we would like to consider the field of civic education, which, in our opinion, unites and complements various subjects and contributes to the school atmosphere and the environment of communication between students and the school staff. In order to maintain this environment at the level of democratic communication and functioning, teachers must possess civic competence, as well as the skills to transfer these competencies and civic knowledge to students. The search for effective methods of gaining civic competencies by teachers is at the heart of our research. Thus, the effectiveness of the methodology of using the information and digital learning environment for the development of teachers' civic competence is tested by the implementation of certain actions by teachers, as well as by creating appropriate opportunities for them in the system of teacher training.

The tools for testing the effectiveness of the information and digital learning environment for this reason are based on diagnosing the extent to which the teacher is aware of the content of civic education, their understanding of how to organize their own professional activities, what technologies and tools to use. We have compiled a questionnaire that was offered to teachers for online responses based on Google forms. Also, during the implementation of our proposed methodology, we monitored the teachers' progress in using the information and digital learning environment to raise their level of civic competence.

Experimental verification of the methodology of using the digital educational environment for the development of teachers' civic competence was conducted in two phases during 2017-2019 - the initial (statement) and the formative, through the implementation of a pedagogical experiment.

In the initial phase, a survey was conducted with teachers, school principals and deputy school principals, and the state of development of their civic competence was determined, as well as their attitude to the use of ICT in the process of working with students and selfimprovement. At this stage of the pedagogical experiment, we developed a questionnaire for teachers and school principals. It was taken into account that the questionnaire was intended for teachers of various school subjects. The questionnaire "Use of ICT for the development of civic competence" consists of three blocks: the 1st block - "Content"; the 2nd block "Organization"; the 3rd block - "Technology".

The results of the study obtained after studying the state of the problem in the initial phase of the experiment revealed the need to develop a methodology for using the information and digital learning environment for the development of teachers' civic competence. It was found that the existing Ukrainian programs and courses for teachers in the system of inservice teacher training do not fully provide the necessary knowledge on how to use ICT for teaching civic education and to create the appropriate environment for this. We revealed only few cases on the special courses for civic education teachers that mention ICT as a tool for this subject area. In the meantime the integration of the two key areas - civic participation and digital literacy as well as the related competencies are outlined by the Law of Ukraine "On Education" and EU guidelines, namely - civic competence and information and communication competence (digital competence). As it was already mentioned, a few Ukrainian in-service teacher thraining institutions are now in the process of introducing such integration. In addition, the process of the teachers' professional growth in the development and the use of information and digital learning environment contributes to the acquisition of 
skills and competencies in other subject areas.

At this stage the authors developed a method of using the information and digital learning environment as a tool for developing teachers' civic competence, the content of which is a combination of goal-setting and knowledge transfer processes; forms, methods and tools of raising teachers' awareness on how to use information and digital learning environment, recommendations for teachers, school principals, methodologists and academics of in-service teacher training institutions and pedagogical universities. The methodological guidelines "The use of digital educational resources in civic education for the development of information and communication and civic competencies of teachers" are designed for 17 teaching hours (seminars, practical classes, trainings -9 hours, lectures -8 hours). The mentioned guidenines consist of three modules: Information-communication and civic competences of teachers as key competences in the digital age; Development of the information and educational environment for the development of teachers'civic competence; Use of digital educational resources and tools of information and educational environment for the development of teachers'civic competence [16].

In the framework of the study we proposed a range of activities for teachers in order to prove in practice the effectiveness of the use of digital tools for the development of civic competence. Also we proposed to use online resources on civic education that can complement the existing school curricula. We hypothesized that by using digital resources for civic education, teachers will at the same time improve their information and communication competence, as well as raise their level of civic competence.

In the process of preparation for the phase of diagnosis of teachers'civic competence in the information and digital learning environment, the following two main approaches were taken into account:

- assessment of the competence by levels and criteria;

- observation of the practical teachers' experience during the implementation of civic education in the classroom as well as observing how they are upgrading their civics skills and what digital resources they are using.

The following criteria were developed for the procedure of diagnosing the development of teachers' civic competence in the information and digital learning environment: cognitive (knowledge), value-motivational (motivation, attitude, values), activity-reflexive (activity and feedback using ICT). According to the developed criteria, three levels of development of teachers' civic competence in the information and digital learning environment were identified: high, middle and low. The criteria were selected in accordance with the approaches proposed in the European frameworks, in particular: Digital Competence Framework for Educators (DigComp.2.0) (2017) [14] and Council of Europe Reference Framework of Competences for Democratic Culture (2018) [15].

Cognitive criterion - the teacher deepens his/her knowledge of the observance and protection of human rights; understands risks and threats in the information and digital learning environment; knows the rules of network etiquette; knows the ways of selfimprovement and self-realization of civic position (including by ICT tools). Valuemotivational criterion - the teacher spreads the ideas of democratic governance, in particular through the media and social networks; encourages colleagues to integrate civic values into educational activities; contributes to the creation of a secure information space for the implementation of civic education in schools; takes into account cultural diversity in the information and digital learning environment. Activity-reflexive criterion - the teacher provides transparent communication through digital tools; shares teaching materials on civic education; implements educational projects and uses ICT to build the school environment; supports student initiatives. We provide specific descriptors for each level (description of learning outcomes). Let's take a closer look at the criteria and descriptors that define them. 
Levels of cognitive criterion. High level: the teacher is deeply aware of the observance and protection of human rights in accordance with the best world and European approaches; fully aware of the risks and threats in the information and digital learning environment, disseminates this knowledge among colleagues and students; knows the rules of network etiquette; knows and chooses effective ways of self-improvement and self-realization of a civil position (including by means of ICT); knows and implements the main components of the information and digital learning environment for civic education at school.

Middle level: the teacher is well acquainted with the implementation and protection of human rights; understands the risks and threats in the information and digital learning environment and knows the rules of conduct during their use, has knowledge of the use of the latest ICT and communication techniques in the information and digital learning environment; knows security measures and protection of personal data; knows the ways of selfimprovement and self-realization of civic position (including by means of ICT).

Low level: the teacher is aware of the issues of observance and protection of human rights; partially aware of the risks and threats in the information and digital learning environment; partially familiar with the ways of communication through social networks and the use of ICT for the implementation of civic education.

Levels of value-motivational criterion. High level: the teacher spreads the ideas of democratic governance and motivates others, in particular through the media and social networks; initiates civic education activities and encourages colleagues to integrate civic values into educational activities; chooses his/her own ways of using the digital educational environment and creates a safe information space for the implementation of civic education in schools; recognizes and takes into account cultural diversity in the information and digital learning environment and creates new tools for intercultural communication based on respect for human rights.

Middle level: the teacher is motivated and interested in spreading the ideas of democratic governance, in particular through the media and social networks; integrates civic values and respect for human rights in the educational process; supports the idea of creating a safe information space for civic education at school; takes into account cultural diversity in the information and digital learning environment.

Low level: the teacher is partially motivated and interested in spreading democratic values among students, in particular by ICT tools; is aware of the importance of safe behavior in the information space; is aware of and takes into account the diversity of cultures.

Levels of activity-reflexive criterion. High level: the teacher creates, uses and distributes among colleagues teaching resources on civic education; organizes transparent communication with students, colleagues, parents regarding civic education, including through digital tools; initiates and develops new educational projects using ICT and promotes the creation of a free, accessible and secure information and digital learning environment for the implementation of civic education in schools; ensures the improvement of knowledge in the field of civic education and ICT.

Middle level: the teacher uses and disseminates teaching resources on civic education among colleagues; organizes transparent communication with students, colleagues, parents regarding civic education, including through digital tools; supports student initiatives, joins educational projects and uses ICT to build a school information and digital learning environment with civic education.

Low level: the teacher makes a limited use of teaching resources on civic education; insufficiently engages in communication with students, parents and colleagues regarding civic education, including through digital tools.

The observation included the following forms and methods of working with teachers, which were used during seminars, webinars, trainings, practical classes and lectures: 
discussions, round table discussions, brainstorming, conversations, exchange of experiences, communication in professional social networks, chats, blogs etc.

Diagnosis of the level of development of teachers' civic competence was carried out by questionnaires (incoming and outgoing) in the control (122 people) and experimental (129 people) groups. At the beginning of the formative phase of the experiment an entrance questionnaire was conducted by self-assessment of the level of development of civic competence and attitude to the use of ICT in professional activities for civic education in accordance with the content of modules and model blocks (target, organizational, technological, diagnostic and effectiveness) and comparison of indicators in control and experimental groups according to the developed questionnaire. The questionnaire included 22 questions in three blocks - content, organization and technology [17].

It should be noted that in the course of the experiment, the experimental group was interviewed through digital tools, namely through a questionnaire submitted to Google forms (https://docs.google.com/forms), to encourage respondents to use this tool and test their ability to use it.

Thus, about $80 \%$ of the respondents' positive answers concerned the importance of the use of ICT, namely: promoting the creation of a free, accessible and secure information space - 93.8\%; understanding the risks and threats in digital environments; knowledge of security and privacy and data protection measures $-79.8 \%$; knowledge of rules of conduct and knowhow on the use of digital technologies and interaction in the information and digital learning environment $-83.7 \%$.
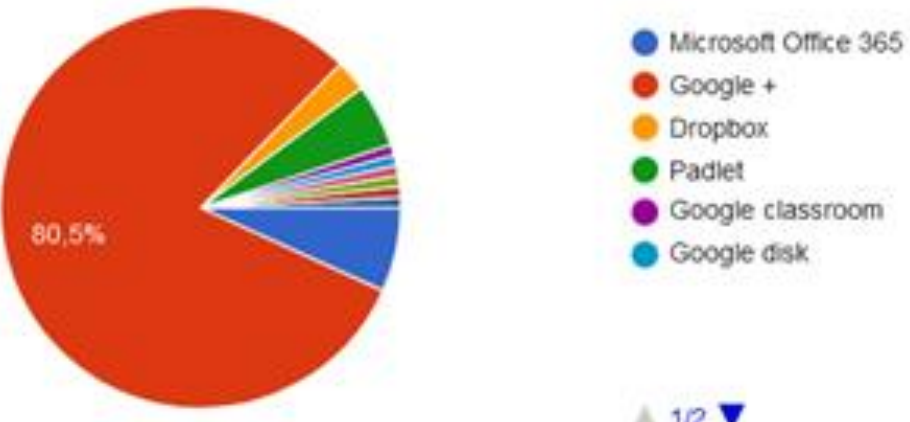

Fig.1.Distribution of the respondents' answers to the question "What cloud services do you use in teaching civic education with students?"

The answers to the questions concerning the teachers'awareness of modern digital tools and the possibilities of their use demonstrated the lack of teachers'awareness and training and the need for methodological support. $18.6 \%$ of positive answers were given to the question "Am I able to protect myself and others from possible dangers in digital environments (for example, from cyber bullying)"; $20.2 \%$ of the respondents said yes to the option "I can create and edit digital content in various formats, express myself digitally on the culture of democracy". Teachers identified Google+ as the most popular cloud service used remotely for training (80.5\%). Teachers also use Microsoft Office 365, Dropbox, Padlet, Google Apps, Google disk and others (Fig. 1).

During the formative phase of the experiment $40.8 \%$ of the respondents in the control group and $42.3 \%$ in the experimental group gave positive answers (completely agree) related to the use of digital resourses and tools for teaching civic education. The average share of positive responses in the control and experimental groups was $29.7 \%$ and $32.1 \%$ for all blocks, respectively, which indicates the homogeneity of the respondents' preparation for the beginning of the experiment. We conducted training activities in the in-service teacher training institutions, followed by another 
survey. The results of the survey were processed by selected methods - the method of mathematical statistics and the method of angular Fisher's transformation [17].

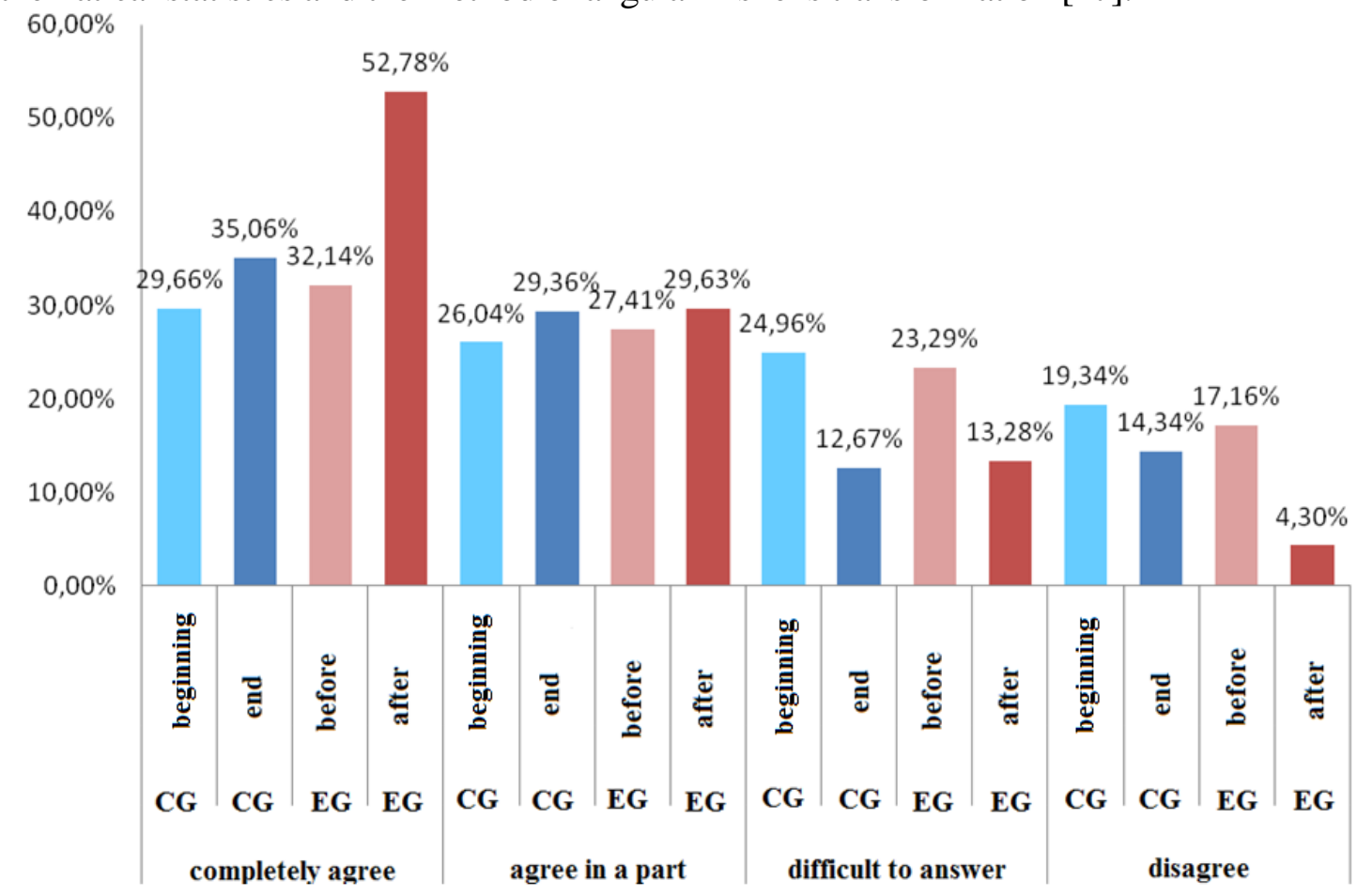

Fig.2. Average relative values in the EG and CG before and after the experimental stage

Notes to Figure 2:

EC - experimental group (pink and burgundy columns);

CG - control group (blue and dark blue columns);

before - before training in the experimental group;

after -after training in the experimental group;

beginning - the beginning of traditional training in the control group;

end - the end of traditional training in the control group.

Thus, on the basis of the obtained data it is possible to draw a conclusion about the positive changes observed in the diagram (Fig. 2) and indicate the effectiveness of the implementation of methodological recommendations during the formative experiment. The most effective the training turned out to be for teachers with "low" indicators, because at the end of the experiment their indicators reached "middle" and "high" levels. At the same time, conducting seminars, trainings and webinars for the target audience with the use of ICToriented technologies allowed teachers and methodologists to join pedagogical communities of interest, become participants in civic education projects and get acquainted with and start using digital tools and cloud technologies. This is also evidenced by the respondents' answers to open questions at the end of the experiment. For example, to the question "Do I and my students participate in online projects?" $12.4 \%$ gave positive answers and $34.1 \%$ of the respondents participated partially. To the open question "If you are involved in online projects, which ones?" the answers of the participants of the experimental group were as follows: EdEra, Prometheus, "My World without Discrimination", "Anti-bullying", "3DDemocracy and World History", "Innovate your Dreams 2019", "e-Twinning", Internet Olympiads, "Learn South Africa", "Energy Efficient Schools. Office 365", "Energy Efficient Schools. New Generation", "Letter Writing Marathon - Amnesty International" and others. At the same time, the teachers emphasized that they also take part in surveys on civic education issues and distance learning courses offered by public organizations and various 
institutions on civic education issues. We believe that the answers to the open question indicate the teachers' motivation to participate in projects and various activities on civic education using ICT. This also demonstrates the dynamics and the changes in the teachers' activity during the training and shows the level of their participation in these activities at the beginning and the end of the experimental stage [17].

The positive dynamics were obtained in both groups at the end of the experiment. However, the experimental group displayed a much higher level of civic competence in the questionnaire blocks. The application of the proposed guidelines "The use of digital educational resources in the field of civic education for the development of teachers' information and communication and civic competencies" during the experiment in the classroom activities has demonstated the positive results and proved the effectiveness of the methodology.

\section{CONCLUSIONS AND RECOMMENDATIONS}

Based on the obtained results we have to conclude that civic education teachers need new, modern resources and tools to deliver both online and blended lessons. For this, it is necessary that the teacher training system make a selection of such resources and provide an opportunity for teachers to familiarize themselves with them. An important finding was that civic education teachers do not have sufficient digital skills and because of this they need to improve their knowledge and practical skills.

The proposed methodology allows us to combine the above tasks and propose a new solution for civic education teachers. The introduction of topics in advanced training courses that integrate ICT and civic education will solve the existing problem in two directions, raising the level of both digital and civic competence of the teacher. In addition, teachers will become familiar with the following issues: the theoretical aspects of the development and practical application of a digital elarning environment, the competency approach in education, the frameworks of civic and digital competencies, etc.

We consider it important to apply the proposed methodology not only in the system of professional development of teachers, school principals and other educators but also at pedagogical universities in preparing students for their future profession.

The development of digital learning environment in educational institutions is an important and necessary condition for increasing the level of teachers' civic competence, which in turn affects the level of civic competence of their students.

The implementation of the methodology should be ensured by institutions of postgraduate pedagogical education and other educational institutions that can improve teachers' professional qualification.

The authors' procedure for creating and using the digital educational environment for the development of teachers' civic competence was built in the process of developing a methodology for using the digital educational environment, which reflects the sequence of creating and using digital educational environment for teacher training.

We see the prospects for further research in creating indicators of the development of civic and digital competencies of teachers and students, as well as monitoring the use of digital resources and an environment for teaching civic education in school.

\section{REFERENCES (TRANSLATED AND TRANSLITERATED)}

[1] V. Bykov etal., "Development of theoretical bases of informatization of education and practical realization of information and communication technologies in education sphere of Ukraine" za red. V.Iu. Bykov, S.H.Lytvynova, Luhovyi V.I.Zhytomyr: ZhDU im. I. Franka, 214 p.,2019. (in Ukrainian) 
[2] S. Lytvynova, "Cloud-oriented learning environment of secondary school", in: Proceedings of the 5th workshop on cloud technologies in education. Kryvyi Rih, Ukraine, pp. 8-12, 2017. (in Ukrainian)

[3] A. Kiv, M. Shyshkina, S. Semerikov, S, Striuk, M. Striuk, H. Shalatska, "When cloud technologies ruled the education", in: CTE 2019 - CEUR, 2643, pp. 1-59, 2020. (in English)

[4] M. Shyshkina, "The General Model of the Cloud-Based Learning and Research Environment of Educational Personnel Training". in: Teaching and learning in a digital world. ICL 2017. Advances in Intelligent Systems and Computing, vol 715, pp. 812-818, Springer. doi:https://doi.org/10.1007/978-3319-73210-7_94. (in English)

[5] M. Schols, J. Bottema, “A National ICT Competency Framework for Student Teacher",in:Society for information technology \& teacher education international conference. Jacksonville, pp.2630 2638,2014.[Online].

Available: https://www.researchgate.net/publication/316078319_A_National_ICT_Competency_Framework_for_St udent_Teachers, Accessed: Nov. 5, 2021. (in English)

[6] EDUsummIT 2019 Summary : Learners and learning contexts: New alignments for the digital age. Ed.: P.Fisser, M. Phillips, Québec City, Canada, 2020.[Online]. Available: https://edusummit2019.fse.ulaval.ca/files/edusummit2019_ebook.pdf, Accessed: October 10, 2021.(in English)

[7] I. Ivaniuk, O. Ovcharuk, M. Leshchenko et al., The development of information and communication competence of teachers in the conditions of cloud-oriented learning environment: a methodical guide. Institute of Information Technologies and Learning Tools of the NAES of Ukraine, Kyiv, Ukraine , p. 128, 2019.(in Ukrainian)

[8] I. Ivaniuk, I. Malytska, O. Ovcharuk et al., "European experience of the teachers' digital competence development in the context of modern educational reforms". Information Technologies and Learning Tools, vol. 3 (65), pp. 316 - 336, 2018. doi: https://doi.org/10.33407/itlt.v65i3.2387. (in Ukrainian)

[9] O. Ovcharuk et al., "The Use of Digital Learning Tools in the Teachers' Professional Activities to Ensure Sustainable Development and Democratization of Education in European Countries", in: The international conference on sustainable futures: environmental, technological, social and economic matters: e3s web of conferences 166, 10019 (ICSF 2020), Kryvyi Rih, Ukraine, 2020. doi: https://doi.org/10.1051/e3sconf/202016610019. (in English)

[10] O. Hrytsenchuk, O. Ovcharuk, "Experimental verification of the effectiveness of the model of information and educational environment as a means of developing civic competence of teachers", Computer in school and family, vol. 2 (158), pp. 52-56, 2020. (in Ukrainian)

[11] M. Leshchenko, et al.: "Democratic Values and Digital Skills of Students' in Higher Educational Establishments of Poland and Ukraine", Advanced education, vol. 1, pp. 105-115, 2020. (in English)

[12] T. Olgers, Escaping the Box of Pandora. Education for Democratic Citizenship: Policies and Regulatory Frameworks. Council of Europe. Strasbourg, 2002. (in English)

[13] K. Duerr, “Citizenship Education in the Context of the European Union: A New Challenge for School and Adult Learning”, Andragoške studije, vol.2, pp. 35-50,2010.(in English)

[14] Digital Competence Framework for Educators (DigCompEdu) /European Commission. Luxembourg, 2017. [Online]. Available: https://ec.europa.eu/jrc/en/digcompedulastaccess 2021/05/11. Accessed: October 10, 2021.(in English)

[15] Council of Europe Reference Framework of Competences for Democratic Culture [Online]. Available: https://www.coe.int/en/web/campaign-free-to-speak-safe-to-learn/reference-framework-of-competencesfor-democratic-culture, 2018. Accessed: October 10, 2021. (in English)

[16] O. Hrytsenchuk, The use of digital educational resources in civic education for the development of information and communication and civic competencies of teachers: a methodical guide. Institute of Information Technologies and Learning Tools of the NAES of Ukraine, Kyiv, Ukraine, 114 p., 2019.(in Ukrainian)

[17] O. Hrytsenchuk, Information and educational learning environment as a tool of developing teachers' civic competence in the Netherlands. Diploma thesis, Institute of Information Technologies and Learning tools of NAES of Ukraine, Kyiv, Ukraine, 2020. [Online]. Available: https://lib.iitta.gov.ua/722866/, Accessed: October 10, 2021.(in Ukrainian)

\section{ЕФЕКТИВНІСТЬ ВИКОРИСТАННЯ ІНФОРМАЦІЙНО-ЦИФРОВОГО НАВЧАЛЬНОГО СЕРЕДОВИЩА ЯК ЗАСОБУ РОЗВИТКУ ГРОМАДЯНСЬКОЇ КОМПЕТЕНТНОСТІ УЧИТЕЛІВ}


Гриценчук Олена Олександрівна кандидат педагогічних наук, старша наукова співробітниця відділу компаративістики інформаційно-освітніх інновацій Інститут інформаційних технологій і засобів навчання НАПН України, м.Київ, Україна ORCID ID 0000-0003-3173-7649

helenekyiv2017@ukr.net

\title{
Овчарук Оксана Василівна
}

доктор педагогічних наук, старша наукова співробітниця,

завідувачка відділом компаративістики інформаційно-освітніх інновацій

Інститут інформаційних технологій і засобів навчання НАПН України, м.Київ, Україна

ORCID ID 0000-0001-7634-7922

oks.ovch@hotmail.com

\section{Трубачев Сергій Іванович}

кандидат технічнихнаук, доцент, викладач кафедри динаміки та міцності машин й опору материалів ММI Національний технічний університет України «Київський політехнічний інститут імені Ігоря

Сікорського», м.Київ, Україна

ORCID ID 0000-0002-7349-9426

strubachev@i.ua

\begin{abstract}
Анотація. У статті наведено результати експериментальної перевірки методики використання інформаційно-цифрового навчального середовища як засобу розвитку цивільної компетентності вчителів. Експериментальна перевірка проводилась під час комплексного дослідження у 2018-2019 роках. За допомогою анкет (вхідної та вихідної) автори дослідження діагностували рівень розвитку громадянської компетентності вчителів у контрольній (122 особи) та експериментальній (129 осіб) групах. Дано опис критеріїв, рівнів та дескрипторів оцінки громадянської компетентності вчителя в інформаційноцифровому навчальному середовищі. Особдива увага вчителів, директорів шкіл, методистів та спеціалістів приділяється підвищенню кваліфікації вчителів щодо використання інформаційних та комунікаційних технологій (ІКТ) для створення та розвитку інформаційно-цифрового навчального середовища в освітніх закладах, а також використання цифрових інструментів у педагогічних навчальних закладах для громадянської освіти у школах. Мета статті - довести ефективність методики використання інформаційно-цифрового навчального середовища як інструменту підвищення рівня громадянської компетентності вчителів та висвітлити процес запровадження громадянської освіти в українських школах. У цьому дослідженні ми розробили основні компоненти методики використання інформаційно-цифрового навчального середовища як засобу розвитку громадянської компетентності вчителів, що становить новизну дослідження. Інформаційно-цифрове навчальне середовище - ефективний інструмент підвищення рівня громадянської компетентності вчителів та інструмент реалізації громадянської освіти в середній школі, що є практичною значущістю дослідження.
\end{abstract}

Ключові слова: громадянська освіта; громадянська компетентність; інформаційнокомунікаційна компетентність; методика; інформаційно-цифрове навчальне середовище; експериментальна перевірка.

\section{ЭФФЕКТИВНОСТЬ ИСПОЛЬЗОВАНИЯ ИНФОРМАЦИОННО-ЦИФРОВОЙ УЧЕБНОЙ СРЕДЫ КАК СРЕДСТВО РАЗВИТИЯ ГРАЖДАНСКОЙ КОМПЕТЕНТНОСТИ УЧИТЕЛЕЙ}

\section{Гриценчук Елена Александровна}

кандидат педагогических наук, старший научный сотрудник отдела компаративистики информационнообразовательных инноваций

Институт информационных технологий и средств обучения НАПН Украины, г.Киев, Украина

ORCID ID 0000-0003-3173-7649

helenekyiv2017@ukr.net 


\title{
Овчарук Оксана Васильевна
}

доктор педагогических наук, старший научный сотрудник,

заведующая отделом компаративистики информационно-образовательных инноваций

Институт информационных технологий и средств обучения НАПН Украины, г. Киев, Украина

ORCID ID 0000-0001-7634-7922

oks.ovch@hotmail.com

\section{Трубачев Сергей Иванович}

кандидат тех.наук, доцент,

преподаватель кафедры динамики и мощности машин и сопротивления материалов ММИ

Национальный технический университет Украины «Киевский политехнический институт имени Игоря

Сикорского», г.Киев, Украина

strubachev@i.ua

\begin{abstract}
Аннотация. В статье представлены результаты экспериментальной проверки методики использования информационно-цифровой обучающей среды как средства развития гражданской компетентности учителей. Экспериментальная проверка проводилась в ходе комплексного исследования в 2018-2019 гг. С помощью анкет (входящей и исходящей) авторы исследования диагностировали уровень развития гражданской компетентности учителей в контрольной (122 человека) и экспериментальной (129 человек) группах. Дано описание критериев, уровней и дескрипторов оценки гражданской компетентности учителя в информационно-цифровой обучающей среде. Особое внимание уделяется отношению учителей, директоров школ, методистов и специалистов к повышению квалификации учителей по использованию информационных и коммуникационных технологий (ИКТ) для создания и развития информационно-цифровой обучающей среды в образовательных учреждениях, а также использованию цифровых инструментов в педагогических учебных заведениях для гражданского образования в школах. Цель статьи - доказать эффективность методики использования информационно-цифровой обучающей среды как инструмента повышения уровня гражданской компетентности учителей и осветить процесс внедрения гражданского образования в украинских школах. В этом исследовании мы разработали основные компоненты методики использования информационно-цифровой обучающей среды как средства развития гражданской компетентности учителей, что составляет новизну исследования. Информационно-цифровая обучающая среда - эффективный инструмент повышения уровня гражданской компетентности учителей и инструмент реализации гражданского образования в средней школе, что является практической значимостью исследования.
\end{abstract}

Ключевые слова: гражданское образование; гражданская компетентность; информационно-коммуникационная компетентность; методика; информационно-цифровая середа обучения; экспериментальная проверка.

\section{(c) BY-NC-SA}

This work is licensed under Creative Commons Attribution-NonCommercial-ShareAlike 4.0 International License. 